\title{
sciendo
}

\section{Application of semi-deviation as a proxy for the expected return estimation in the Croatian equity market}

\author{
Denis Dolinar \\ University of Zagreb, Faculty of Economics \& Business, Croatia, \\ ddolinar@efzg.hr \\ Davor Zoričić \\ University of Zagreb, Faculty of Economics \& Business, Croatia, \\ dzoricic@efzg.hr \\ Zrinka Lovretin Golubić \\ University of Zagreb, Faculty of Economics \& Business, Croatia, \\ zlovretin@efzg.hr
}

\begin{abstract}
In the field of portfolio management the focus has been on the out-of-sample estimation of the covariance matrix mainly because the estimation of expected return is much more challenging. However, recent research efforts have not only tried to improve the estimation of risk parameters by expanding the analysis beyond the mean-variance setting but also by testing whether risk measures can be used as proxies for the expected return in the stock market. In this research, we test the standard deviation (measure of total volatility) and the semi-deviation (measure of downside risk) as proxies for the expected market return in the illiquid and undeveloped Croatian stock market in the period from January 2005 until November 2017. In such an environment, the application of the proposed methodology yielded poor results, which helps explain the failure of the out-of-sample estimation of the maximum Sharpe ratio portfolio in earlier research in the Croatian equity market.
\end{abstract}

Keywords: expected return estimation, illiquid and undeveloped equity market, semideviation.

JEL classification: G11, G12

DOI: 10.2478/crebss-2019-0002

Received: May 11, 2018

Accepted: April 02, 2019

\section{Introduction}

The inefficient risk to reward ratio of stock market capitalisation-weighted indices has been exposed and well documented in the period stretching from the end of the $20^{\text {th }}$ to the beginning of the $21^{\text {st }}$ century. In the years that followed, facilitated by the rise of Exchange-Traded Funds, a lot of research has been devoted to efficient indexation as better risk to reward ratio indices clearly needed to be made available to investors. 
Among other approaches, Risk Parity and Diversified Risk Parity portfolios introduced by Maillard et al. (2010), Maximum Diversification Ratio portfolios introduced by Choveifaty and Coignard (2008) and Max Decorrelation portfolios introduced by Christoffersen et al. (2012) can be pointed out.

As presented in the Amenc et al. (2013) all of these approaches (including the Global Minimum Variance portfolio introduced in the Modern Portfolio Theory by Markowitz) focus only on the estimation of volatilities and/or correlations of stocks in portfolio. This implies, that at least either expected returns or Sharpe ratios have to be identical for all stocks in each of the above approaches in order to meet optimality condition - maximum diversification leading to exposure to systematic risk only. Only the Maximum Sharpe Ratio portfolio is optimal by construction (even if the Capital Asset Pricing Model - CAPM assumptions do not hold) due to the fact that apart from estimation of volatilities and correlations it requires also the estimation of expected returns.

Although even the simple methods for improved estimates of volatilities and correlations produce good results, see for instance Ledoit and Wolf (2004), the same cannot be said for the estimation of expected returns as it is generally much more challenging to estimate the central moments of odd order as opposed to the even ones. However, the works of Martellini (2008) and Amenc et al. (2011) address this issue by using risk measures as proxies for expected returns of stocks in portfolio. The underlying assumption being that the greater the risk of an asset the higher the return should be required. In his research Martellini (2008) provides substantial evidence that even if a simple measure of risk is used in the form of total volatility there is a potential for outperforming market-cap weighted and equally weighted benchmarks in terms of out-of-sample Sharpe ratio. Amenc et al. (2011) take this idea a step further and use semi-deviation, a downside measure of risk, as a proxy for expected return relying on a rationale that investors should only be concerned with the deviations below the mean.

Following the work of Martellini (2008) and Amenc et al. (2011) in this paper, we examine the possibility of expected return estimation in the illiquid and undeveloped Croatian stock market by applying the proposed methodology. The paper by Zoričić et al. (2018a), for instance, demonstrated the importance of conducting research in the illiquid and undeveloped Croatian stock market since their research findings showed that it is possible to estimate volatilities and correlations of stocks (albeit without success regarding outperforming the benchmark index) regardless of such specific environment. Bearing this in mind the research results focusing on the improvement of the expected return estimation can further shed light on the failure of Maximum Sharpe Ratio portfolio estimation attempt by Dolinar et al. (2017) and provide insight on how to improve this strand of research in the future. The ultimate goal of such research efforts is to offer an efficient alternative to cap-weighted benchmark even in markets usually found unappealing to major international institutional investors due to its specific characteristics.

Our aim is not to model the relationship between the risk and return but rather to test, under the aforementioned austere conditions, the valuable insight revealed by Martellini (2008) that the principle relation between the two can be used to improve the estimation of returns. Such approach makes this research, to the best of our knowledge, the first analysis of this kind for any illiquid and undeveloped market, including the Croatian, which is further elaborated in the literature review. Furthermore, in addition to the results presented in Martellini (2008) we add a panel data analysis to the methodological framework in order to provide a comprehensive analysis of performance of risk measures used. 
The next section of the paper refers to the literature review followed by the detailed description of the methodology and collected data. Research findings report the research results and discuss the implications followed by the Conclusion.

\section{Literature review}

The relationship between the risk and return is one of the most closely monitored and long studied in finance. For the sake of brevity we will point out only the most relevant strands of research related to our paper stating the most influential and recent representative papers.

Ever since the formulation of the Modern Portfolio Theory and subsequently the CAPM, various approaches dedicated to this particular topic have emerged. Arguably, the most productive one (at least according to the classification criterion taken here) is the one analysing the cross section of returns since it encompasses all the modifications and expansions of the famous CAPM - a special case of the single factor model. As pointed out in, for instance, Malkiel and XU (1997) the focus regarding factor models is in identifying one or more (such as in the famous Fama French threefactor model (Fama, French, 1993)) systematic risk factors in order to determine the systematic and idiosyncratic risk return relation. However, since in this paper we do not deal with risk factors but rather with risk measures, more closely related research refers to Huang et al. (2012), who explore the relation between the extreme downside risk measure and expected return, and to Feunou et al. (2017) and Bollerslev et al. (2018) who deal with variance decomposition and expected return. Similar research also include Verousis and Voukelatos (2018) and Ang et al. (2006a, b).

Nevertheless, all the above-mentioned research investigates the cross section of return. Therefore, the other big block of research is devoted to the intertemporal relation between risk and return focusing on modelling the expected return in relation to risk over time. Glosten et al. (1993) apply a GARCH-M model for this purpose and provide a brief overview of the most important previous research efforts in this field. A more recent research by Bollerslev et al. (2009) can be mentioned here, but the research by Bali et al. (2009) is more closely related to the research presented in this paper as the authors test different downside risk measures in order to try to model the expected return over time.

However, as already mentioned in the introduction, neither the cross section nor the time series based research testing the risk measures and expected return can be compared to the analysis conducted in this research. This is due to the fact that the main idea in Martellini (2008), backed by the findings in the mentioned research, was to test whether (as Martellini refers to it on p. 40) a "crude and simplistic measure" such as the volatility of the returns can be used as their proxy. The focal point of the research does not include modelling the expected returns but rather a thorough out-of-sample testing of whether relying on the stocks' volatilities can improve return estimation. In the research a sample of 682 stocks was used for which out-of-sample estimates of returns in the period 1985-2004 were obtained and grouped according to risk (measured by volatility) in 5 different portfolios. Details about the procedure are reported in the following section of the paper. Results revealed growing risk premiums, although only the highest one was found to be statistically significant. Encouraged by the findings the second part of the research briefly demonstrates how the finding can be easily exploited to model the expected return in the cross section (factor model) or times series (GARCH) context.

The research for the Croatian stock market includes various factor model testing, ranging from CAPM and its modifications in Fruk and Huljak (2003), Perković (2011), Džaja and Aljinović (2013), Odobašić et al. (2014), Minović and Živković (2014), to 
Fama French in Dolinar (2013) and Zoričić et al. (2018b). Further, the APT multi-factor models are described in Benaković and Posedel (2010), Dolinar et al. (2014) and Gardijan and Škrinjarić (2015).

Regarding time-series modelling of expected return GARCH models have been used by Arnerić et al. (2006), Jurun et al. (2007), Arnerić et al. (2009), Škrinjarić and Šego (2016). Additionally, Kunovac (2011) applied market regimes, Škrinjarić, and Kojić (2014) and Škrinjarić and Šostarić (2014) applied Markov chain method in order to improve return estimation.

Out of all the mentioned research only Gardijan and Škrinjarić (2015) and Škrinjarić and Šego (2016) tested the risk measures by employing the higher order moments in their analysis, however, in the cross section and time series setting respectively. Unfortunately, up to now, there are not any published research available in the Croatian or other illiquid and undeveloped market, to enable a comparison to our results.

\section{Data and methodology}

In order to link the expected return estimation to volatility estimation, we follow Martellini (2008) who demonstrated that observed total volatility of a stock could be used as a proxy for the stock's expected return. Stock's total volatility is calculated as standard deviation by using the following formula:

$$
S_{i}=\sqrt{\frac{\sum_{t=1}^{T}\left(r_{i, t}-\bar{r}_{i}\right)^{2}}{T-1}},
$$

where $r_{i, t}$ represents the realised return of stock $i$ in period $t, \bar{r}_{i}$ represents the arithmetic average of realised returns and $T$ represents number of periods in the sample.

In order to take into consideration the aspect of utmost investor's interest - that is the uncertainty about the extent of actual return being below the expected return we also test semi-deviation as a measure of downside risk. Such measure as proposed by Amenc et al. (2011) takes into account only deviations below the mean, therefore it is considered as more purposeful measure of risk. Semi-deviations are calculated using the following formula:

$$
\mu_{i}=\sqrt{\frac{\sum_{t=1 ; r_{i, i}<\bar{r}_{i}}^{T}\left(r_{i, t}-\bar{r}_{i}\right)^{2}}{T^{*}}},
$$

where $\mu_{i}$ represents the semi-deviation of realised returns of stocks $i, r_{i, t}$ represents the realised return of stock $i$ in period $t, \bar{r}_{i}$ represents the arithmetic average of realised returns and $T^{*}$ represents the number of periods in the sample where the realised return is below the mean.

The research is based on the 62 stocks that were listed on The Zagreb Stock Exchange (ZSE) and included in the CROBEX index at some point in time in the period from January 2005 until November 2017. The CROBEX index is the oldest and largest (broad-based) index in the Croatian financial market introduced in 1997 by the ZSE, therefore the vast majority of analysis relies on it when the Croatian equity market is being considered.

Over the entire observed period we use weekly excess returns (total returns above risk-free rate). Standard deviation and semi-deviation are calculated for multiple samples based on a 52 week rolling window of returns for stocks that had at least 26 weeks of trading and were traded both in the last week of the sample and in the first out-of-sample week (trading in the mentioned weeks is important because it allows for the calculation of the weekly out-of-sample return for the stock). Thus, when 
calculating standard deviations and semi-deviations of stocks in each sample formulas (3) and (4) are used respectively, as follows:

and

$$
s_{i, t}=\sqrt{\frac{\sum_{t-52}^{t-1}\left(r_{i, t}-\overline{r_{i}}\right)^{2}}{52-1}}
$$

$$
\mu_{i, t}=\sqrt{\frac{\sum_{t-52 ; r_{i, t}<\bar{r}_{i}}^{t-1}\left(r_{i, t}-\overline{r_{i}}\right)^{2}}{T^{*}}}
$$

In order to validate the use of standard deviation and semi-deviation as proxy measures of expected returns of stocks, the following three methods were employed:

(1) a time-series analysis of risk premium related to volatility (like in Ang et al. (2006) and Martellini (2008)),

(2) an analysis of cross-sectional regressions of realised returns on estimated risk measures over time (like Fama and MacBeth (1973) and Martellini (2008)), and

(3) a panel data analysis of realised returns on estimated risk measures.

When searching for time-series evidence of risk premium related to volatility (i.e. whether high volatility stocks have higher average return than low volatility stocks) we follow Martellini (2008) and sort individual stocks into equally-weighted quartiles (portfolios) based on observed volatility measures - standard deviation (total volatility) and semi-deviation (downside risk measure), respectively. Both risk measures are calculated based on returns of the previous 52 weeks ( 1 year). We hold these portfolios for 1 week and estimate out-of-the sample one-week return for each quartile (portfolio). The process is repeated 672 times over and a time-series of weekly returns for the quartiles is obtained during the period from January 2005 until November 2017 (672 out-of-sample estimates of weekly return for each portfolio). Risk premiums are computed as the difference between the average returns of $4^{\text {th }}$ quartile and each of the other three quartiles (i.e. average $Q_{4}-Q_{1}$ return, average $Q_{4}-Q_{2}$ return and average $Q_{4}-Q_{3}$ return). Finally, $p$-values indicate whether these risk premiums are statistically significant.

Further search for the volatility related risk premium is done cross-sectionally. Following Martellini (2008), at each point in time (672 weeks), we run cross-sectional regression of realised return on the observed volatility measures, standard deviation and semi-deviation, using the formulas (5) and (6). Further, we average the slope coefficient in these regressions across time $\bar{\gamma}$ to obtain an estimate for the unconditional slope coefficient. To indicate if these risk premiums are statistically significant the t-statistic for the slope coefficient is calculated using the formula (7).

The appropriate formulas for the realised returns of stock $i$ in period $t, r_{i}$, , are given, respectively, as follows:

and

$$
\begin{gathered}
r_{i, t}=\alpha_{i, t}+\gamma_{t} s_{i, t}+\varepsilon_{i, t} \\
r_{i, t}=\alpha_{i, t}+\gamma_{t} \mu_{i, t}+\varepsilon_{i, t}
\end{gathered}
$$

$$
t_{\gamma}=\frac{\bar{\gamma}}{\frac{\sigma_{\gamma}}{\sqrt{T}}}
$$

Since our dataset represents longitudinal observation of companies (stocks) over time, we also perform panel data analysis in order to utilise all its advantages and to strengthen research conclusions. When defining the form of a panel model, the oneway time random effects panel model was chosen using the formulas (8) and (9), as follows:

$$
r_{i, t}=\alpha_{t}+\gamma s_{i, t}+\varepsilon_{i, t},
$$


and

$$
r_{i, t}=\alpha_{t}+\gamma \mu_{i, t}+\varepsilon_{i, t}
$$

Finally, the statistical diagnostics tests applied for this research were as follows: the F-test for poolability, the Breusch-Pagan Lagrange multiplier (LM) and the Sargan Hansen test, and they all support the choice of this panel model form. Again, the pvalues of the slope coefficient were used to indicate whether volatility related risk premiums are shown to be statistically significant.

\section{Research findings}

Table 1 shows time-series analysis of weekly out-of-sample returns for the quartiles (i.e. portfolios described in the second section) during the period from January 2005 until November 2017. These portfolios are constructed for both risk measures (return proxies), standard deviation and semi-deviation, respectively. The volatility related risk premiums are defined as a difference between the average annualised return of 4 th quartile and return of other three quartiles. The results show that expected monotonic increase of annualised return (as a function of volatility) is not present. Both risk measures exhibit negative risk premiums between the top quartile (25\% of the highestvolatility stocks) and the bottom quartile (25\% of the lowest-volatility stocks) indicating that stocks with low volatility earn higher returns than stocks with high volatility. Finally, $\mathrm{p}$-values confirm that these risk premiums (discounts) are statistically insignificant. Thus both, standard deviation and semi-deviation, should not be taken as proxies of expected return for Croatian stocks over the observed period.

Table 1 Annualised performance of quartiles and risk premiums/discounts

\begin{tabular}{|l|c|c|c|c|c|c|}
\hline & \multicolumn{3}{|c|}{ Standard deviation } & \multicolumn{3}{c|}{ Semi-deviation } \\
\cline { 2 - 6 } & $\begin{array}{c}\text { Annualised } \\
\text { return (Qx) }\end{array}$ & $\begin{array}{c}\text { Annualised } \\
\text { premium/discount } \\
\left(Q_{4}-Q_{x}, x=1, \ldots, 4\right)\end{array}$ & $p$-values & $\begin{array}{c}\text { Annualised } \\
\text { return }\end{array}$ & $\begin{array}{c}\text { Annualised } \\
\text { premium/discount } \\
\left(Q_{4}-Q_{x}, x=1, . .4\right)\end{array}$ & $p$-values \\
\hline Quartile 1 & $9.84 \%$ & $-1.99 \%$ & 0.9919 & $9.58 \%$ & $-0.68 \%$ & 0.9973 \\
Quartile 2 & $8.71 \%$ & $-0.86 \%$ & 0.9961 & $7.97 \%$ & $0.92 \%$ & 0.9959 \\
Quartile 3 & $6.17 \%$ & $1.68 \%$ & 0.9920 & $6.73 \%$ & $2.17 \%$ & 0.9899 \\
Quartile 4 & $7.85 \%$ & $0.00 \%$ & NA & $8.90 \%$ & $0.00 \%$ & NA \\
\hline
\end{tabular}

Q.: quartile return is calculated as arithmetic mean and annualised as a geometric average. Source: Authors' calculation.

Cumulative effect of volatility related risk premium/discount is depicted in Figure 1 (for standard deviation) and Figure 2 (for semi-deviation). Absence of self-evident positive trend clearly proves the failure of both risk measures over time. Namely, quite opposite to finding by Martellini (2008) for the US market for which the premium between the highest and lowest volatility stocks was the largest and significant, for the Croatian stock market this measure performs the worst of all. Furthermore, in the Croatian stock markets both premiums and discounts (although not significant) are present. 


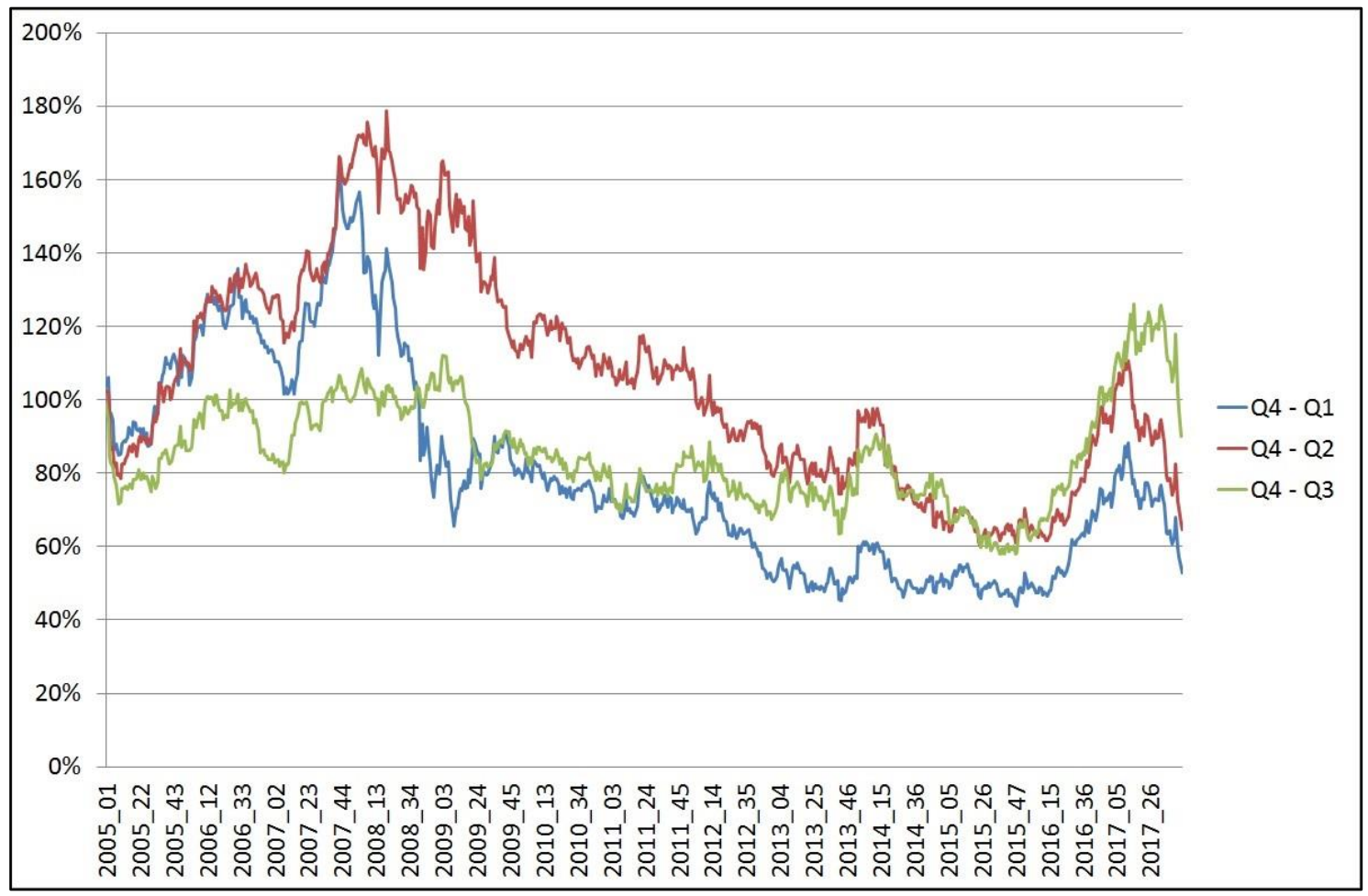

Figure 1 Equally-weighted top-minus-bottom cumulative returns with standard deviation as a proxy, 2005-2017

Source: Authors' calculation.

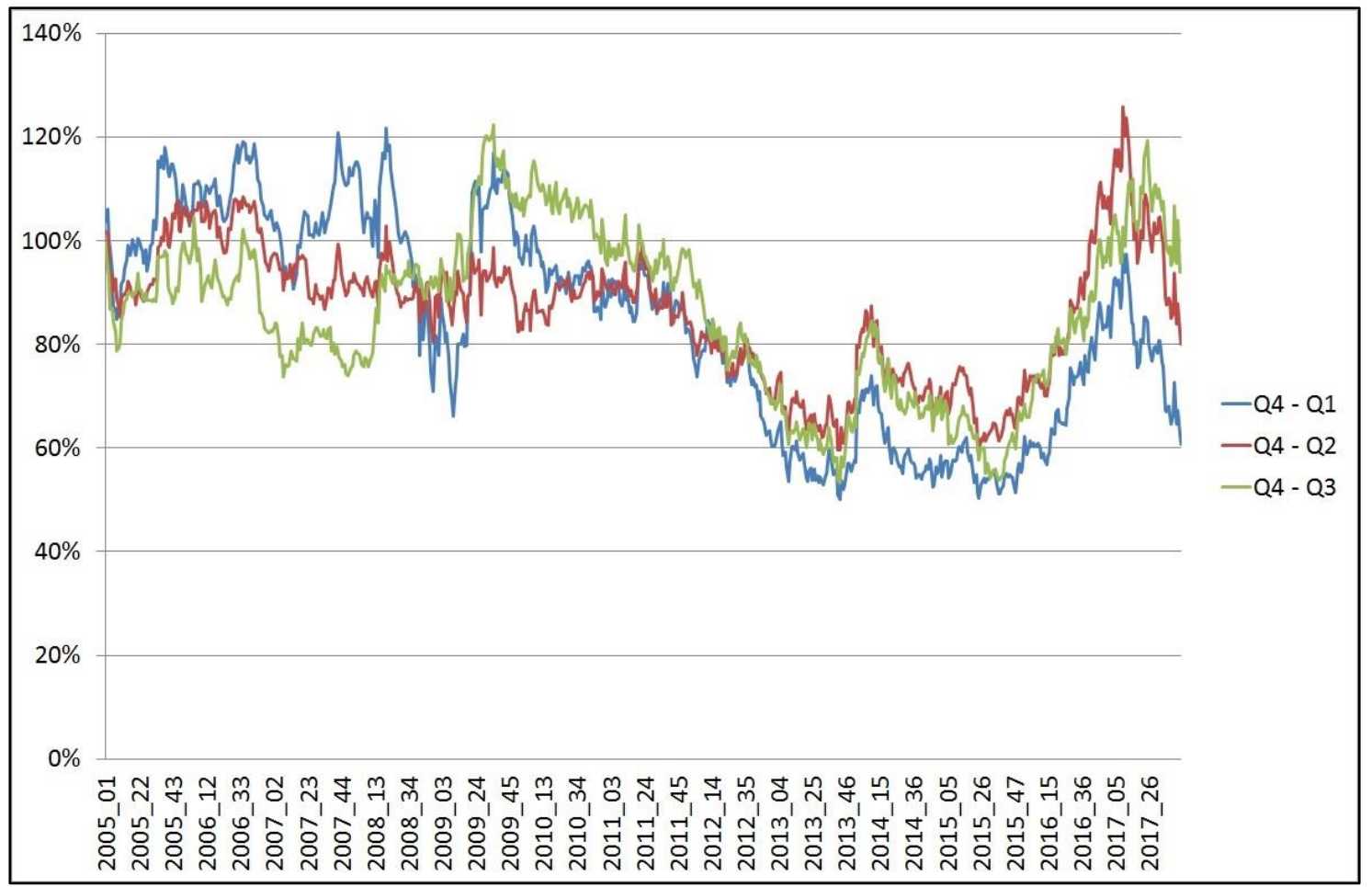

Figure 2 Equally-weighted top-minus-bottom cumulative returns with semi-deviation Source: Authors' calculation. as a proxy, 2005-2017

Table 2 shows analysis of weekly cross-sectional regressions of realised returns on standard deviation and semi-deviation estimated over time. For both measures, 
average slope coefficient $\bar{\gamma}$ is negative and statistically insignificant, which shows that they do not have explanatory power for the cross-section of stock returns.

Table 2 Average cross-sectional risk premiums and their significance

\begin{tabular}{|c|c|c|c|}
\hline Slope coefficient $\gamma$ for: & Average $(\bar{\gamma})$ & Standard deviation $\left(\sigma_{\gamma}\right)$ & p-value \\
\hline Standard deviation $(s)$ & -0.002 & 0.570 & 0.928 \\
Semi-deviation $(\mu)$ & -0.003 & 0.718 & 0.901 \\
\hline
\end{tabular}

Source: Authors' calculation.

Finally, table 3 shows panel regression estimation of risk premiums related to standard deviation and semi-deviation estimated over time. As indicated in the previous section one-way time random effects panel model was chosen. The reported results are in line with previous time-series and cross-sectional analysis.

For both risk measures, the slope coefficient $(Y)$ is statistically significant only in the year 2012, albeit with negative slope coefficient suggesting again unexpected i.e. irrational relationship between risk and return. This again shows that the proposed risk measures do not possess explanatory power when describing stock returns.

Table 3 Overview of risk premiums and their significance

\begin{tabular}{|c|c|c|c|c|}
\hline \multirow[b]{2}{*}{$\begin{array}{l}\text { Observation } \\
\text { period }\end{array}$} & \multicolumn{2}{|c|}{ Standard deviation } & \multicolumn{2}{|c|}{ Semi-deviation } \\
\hline & $\begin{array}{c}\hat{\alpha}_{t} \\
\text { (robust SE) }\end{array}$ & $\begin{array}{c}\hat{\gamma} \\
\text { (robust SE) }\end{array}$ & $\begin{array}{c}\hat{\alpha}_{t} \\
\text { (robust SE) }\end{array}$ & $\begin{array}{c}\hat{\gamma} \\
\text { (robust SE) }\end{array}$ \\
\hline 2005 & $\begin{array}{l}0.0122^{* *} \\
(0.0056)\end{array}$ & $\begin{array}{l}-0.0111 \\
(0.0461)\end{array}$ & $\begin{array}{l}0.0114^{*} \\
(0.0062)\end{array}$ & $\begin{array}{l}-0.0029 \\
(0.0693)\end{array}$ \\
\hline 2006 & $\begin{array}{c}0.0104^{* * *} \\
(0.0029)\end{array}$ & $\begin{array}{l}-0.0034 \\
(0.0334)\end{array}$ & $\begin{array}{c}0.0103^{* * *} \\
(0.0032)\end{array}$ & $\begin{array}{c}-0.003 \\
(0.0572)\end{array}$ \\
\hline 2007 & $\begin{array}{c}0.0056 \\
(0.0037) \\
\end{array}$ & $\begin{array}{c}0.0934 \\
(0.0582) \\
\end{array}$ & $\begin{array}{l}0.0096^{* *} \\
(0.0037) \\
\end{array}$ & $\begin{array}{c}0.0252 \\
(0.0748) \\
\end{array}$ \\
\hline 2008 & $\begin{array}{c}-0.013^{* * *} \\
(0.0043) \\
\end{array}$ & $\begin{array}{l}-0.1402 \\
(0.1374)\end{array}$ & $\begin{array}{c}-0.0172^{* * *} \\
(0.0062)\end{array}$ & $\begin{array}{l}-0.0758 \\
(0.1974) \\
\end{array}$ \\
\hline 2009 & $\begin{array}{c}0.0037 \\
(0.0046)\end{array}$ & $\begin{array}{l}-0.0087 \\
(0.0893) \\
\end{array}$ & $\begin{array}{c}-0.002 \\
(0.0051)\end{array}$ & $\begin{array}{c}0.0581 \\
(0.1015)\end{array}$ \\
\hline 2010 & $\begin{array}{l}-0.0003 \\
(0.0041)\end{array}$ & $\begin{array}{c}0.0089 \\
(0.0647)\end{array}$ & $\begin{array}{c}-0.0014 \\
(0.0044)\end{array}$ & $\begin{array}{c}0.0318 \\
(0.0916)\end{array}$ \\
\hline 2011 & $\begin{array}{l}-0.0068^{*} \\
(0.0039) \\
\end{array}$ & $\begin{array}{c}0.0582 \\
(0.0827)\end{array}$ & $\begin{array}{c}-0.004 \\
(0.0038)\end{array}$ & $\begin{array}{l}0.0074 \\
(0.095) \\
\end{array}$ \\
\hline 2012 & $\begin{array}{l}0.008^{* * *} \\
(0.0031) \\
\end{array}$ & $\begin{array}{c}-0.1352^{* * *} \\
(0.0519)\end{array}$ & $\begin{array}{l}0.0073^{*} \\
(0.0037) \\
\end{array}$ & $\begin{array}{l}-0.1439 * \\
(0.0757) \\
\end{array}$ \\
\hline 2013 & $\begin{array}{c}0.0035 \\
(0.0037)\end{array}$ & $\begin{array}{c}-0.0358 \\
(0.078)\end{array}$ & $\begin{array}{c}0.0022 \\
(0.0047)\end{array}$ & $\begin{array}{l}-0.0135 \\
(0.1145)\end{array}$ \\
\hline 2014 & $\begin{array}{c}0.0007 \\
(0.0026) \\
\end{array}$ & $\begin{array}{c}0.0296 \\
(0.0523) \\
\end{array}$ & $\begin{array}{c}0.0008 \\
(0.0037) \\
\end{array}$ & $\begin{array}{c}0.0355 \\
(0.0998) \\
\end{array}$ \\
\hline 2015 & $\begin{array}{l}-0.0012 \\
(0.0025)\end{array}$ & $\begin{array}{c}0.0554 \\
(0.0588)\end{array}$ & $\begin{array}{c}0.0007 \\
(0.0023)\end{array}$ & $\begin{array}{c}0.0228 \\
(0.0654)\end{array}$ \\
\hline 2016 & $\begin{array}{c}0.0007 \\
(0.0037)\end{array}$ & $\begin{array}{l}0.0983 \\
(0.096) \\
\end{array}$ & $\begin{array}{l}-0.0002 \\
(0.0038) \\
\end{array}$ & $\begin{array}{c}0.1385 \\
(0.1153) \\
\end{array}$ \\
\hline $2017 \S$ & $\begin{array}{r}-0.0004 \\
(0.005) \\
\end{array}$ & $\begin{array}{l}-0.0305 \\
(0.118) \\
\end{array}$ & $\begin{array}{c}0.0011 \\
(0.0063)\end{array}$ & $\begin{array}{c}-0.067 \\
(0.1625)\end{array}$ \\
\hline $\begin{array}{c}\text { Overall } \\
2005-2017 \S\end{array}$ & $\begin{array}{c}0.0012 \\
(0.0013)\end{array}$ & $\begin{array}{c}0.0049 \\
(0.0215)\end{array}$ & $\begin{array}{l}0.0015 \\
0.0015\end{array}$ & $\begin{array}{l}-0.0006 \\
(0.0325)\end{array}$ \\
\hline
\end{tabular}

Notes: Significance indicators: *** $1 \%, * * 5 \%, * 10 \%$. "Robust SE" mean unbiased standard errors of coefficients under heteroscedasticity.

$\S$ Data for 2017 until November only are included

Source: Authors' calculation. 


\section{Conclusion}

This paper examines the possibility of improving the estimation of expected return in the illiquid and undeveloped Croatian market by relying on risk measures as proxies for the expected return, a concept that yielded attractive results in the developed markets. The main goal of such attempt is that, if it proves to be successful, it could encourage (due to its simplicity) research aiming to provide out-of-sample estimates of Maximum Sharpe ratio portfolios which could offer the best possible diversification benefits to investors. However, the findings of this research, unfortunately, suggest that it is not possible to estimate the expected return in the Croatian market by using the total volatility and semi-deviation as proxies in the analysed period.

Unlike for the US stock market for the Croatian stock market the use of such proxies did not yield any significant results. To make matters worse in the case of Croatian market instead of premiums we find evidence of discounts related to increase in riskiness in some cases and also find that, unfortunately, the difference in returns of the most volatile (riskiest) and least volatile (riskiest) stocks performs the worst. Furthermore, the use of semi-deviation as a measure of downside risk, contrary to expectations, does not seem to outperform standard deviation (total volatility measure) in this environment. Cross sectional and panel regressions corroborated findings further and showed that risk proxies do not possess explanatory power related to stock returns with only one exception in the case of year 2012 for the panel regression (in which case the results suggest irrational negative relationship - a rise in riskiness causes a decrease in return). Future research could, however, test additional risk measures as proxies such as skewness and kurtosis, but also VaR, expected shortfall and other measures mentioned in some of the research in the Literature review section of this paper.

These findings help explain the failure of the Maximum Sharpe Ratio portfolio estimation attempt by earlier research in the Croatian equity market as there is evidence now that the required expected return estimates probably performed poorly. This implies further that in such market conditions it is better to choose a proxy for an optimal target portfolio (Maximum Sharpe Ratio portfolio) than to try to estimate the optimal target itself due to large estimation risk. However, in this case one needs to be aware that specific risks have not been eliminated entirely and that one has to account for specific exposures depending on the proxy used.

Lastly, the possibility for further stock screening has to be considered due to data reliability and liquidity issues. Therefore, stocks below a specified threshold turnover value could be ignored in analysis or a measure of liquidity could be tested as a proxy for return. However, there may not be too much room for filtering out the bad data in a small market.

\section{References}

1. Ang, A., Chen, J., Xing, Y. (2006a). Downside risk. The Review of Financial Studies, Vol. 19, No. 4, pp. 1191-1239.

2. Ang, A., Hodrick, R., Xing, Y., Zhang, X. (2006b). The Cross Section of Volatility and Expected Returns. Journal of Finance, Vol. 51, No. 1, pp. 259-299.

3. Amenc, N., Goltz, F., Martellini, L., Retkowsky, P. (2011). Efficient Indexation: An Alternative to Cap-Weighted Indices. The Journal of Investment Management, Vol. 9, No. 4, pp. 1-23.

4. Amenc, N., Goltz, F., Martellini, L. (2013). Smart Beta 2.0. Nice, France: EDHEC-Risk Institute.

5. Arnerić, J., Jurun, E., Pivac, S. (2006). Parametric Forecasting of Value at Risk Using Heavy Tailed Distribution. In: Proceedings of the 11 th International Conference on Operational Research. Pula, pp. 65-75.

6. Arnerić, J., Jurun, E., Pivac, S. (2009). Multivariate risk-return decision making within dynamic estimation. Revista investigación operacional, Vol. 30, No. 1, pp. 11-19. 
7. Bali, T. G., Demirtas, K. O., Levy, H. (2009) Is There an Intertemporal Relation between Downside Risk and Expected Returns? Journal of Financial and Quantitative Analysis, Vol. 44, No. 4, pp. 883-909.

8. Benaković, D., Posedel, P. (2010). Do macroeconomic factors matter for stock returns? Evidence from estimating a multifactor model on the Croatian market. Business systems research, Vol. 1, No. 1-2, pp. 1-50.

9. Bollerslev, T., Li, S. Z., Zhao, B. (2018). Good Volatility, Bad Volatility, and the Cross Section of Stock Returns. Journal of Financial and Quantitative Analysis, forthcoming, pp. 1-57.

10.Bollerslev, T., Tauchen, G., Zhou, H. (2009). Expected Stock Returns and Variance Risk Premia. The Review of Financial Studies, Vol. 22, No. 11, pp. 4463-4492.

11.Choueifaty, Y., Coignard, Y. (2008). Toward Maximum Diversification. Journal of Portfolio Management, Vol. 35, No. 1, pp. 40-51.

12.Christoffersen, P., Errunza, V., Jacobs, K., Jin, X. (2012). Is the Potential for International Diversification Disappearing? A Dynamic Copula Approach. Review of Financial Studies, Vol. 25, No. 12, pp. 3711-3751.

13.Dolinar, D. (2013). Test of the Fama-French three-factor model in Croatia. UTMS Journal of Economics, Vol. 4, No. 2, pp. 101-112.

14.Dolinar, D., Orsag, S., Sudar, A. (2014). Macroeconomic factors and stock returns - evidence from Croatian stock market. In: WDSI 2014 proceedings: Western Decision Sciences Institute forty third annual meeting Napa, California: Western Decision Sciences Institute.

15.Dolinar, D., Zoričić, D., Kožul, A. (2017). Towards the Estimation of an Efficient Benchmark Portfolio: The Case of Croatian Emerging Market. Zagreb international review of economics \& business, Vol. 20, No. S1, pp. 13-24.

16.Džaja, J., Aljinović, Z. (2013). Testing CAPM model on the emerging markets of the Central and Southeastern Europe. Croatian Operational Research Review (CRORR), Vol. 4, No. 1, pp. 164-175.

17.Fama, E. F., MacBeth, J. D. (1973). Risk, Return, and Equilibrium: Empirical Tests. Journal of Political Economy, Vol. 81, No. 3, pp. 607-636.

18.Fama, E. F., French, K. R. (1993). Common Risk Factors in the Returns on Stocks and Bonds. Journal of Financial Economics, Vol. 33, No. 1, pp. 3-56.

19.Feunou, B., Lopez Aliouchkin, R., Tédongap, R., XU, L. (2017). Variance Premium, Downside Risk, and Expected Stock Returns. Working paper, pp. 1-50.

20.Fruk, M., Huljak, I. (2004). Testiranje Sharpe-Lintnerova modela na Zagrebačkoj burzi. Financijska teorija i praksa, Vol. 28, No. 1, pp. 77-91.

21.Gardijan, M., Škrinjarić, T. (2015). Estimating investors preferences towards portfolio return distribution in investment funds. CRORR Croatian Operational Research Review, Vol. 6, No. 2, pp. 1-16.

22. Glosten, L. R., Jagannathan, R., Runkle, D. E. (1993). On the Relation between the Expected Value and the Volatility of the Nominal Excess Return on Stocks. The Journal of Finance, Vol. 48, No. 5, pp. 1779-1801.

23.Huang, W., Liu, Q., Rhee, S. G., Wu, F. (2012). Extreme downside risk and expected stock returns. Journal of Banking \& Finance, Vol. 36, No. 5, pp. 1492-1502.

24.Jurun, E., Pivac, S., Arnerić, J. (2007). Historical and Prognostic Risk Measuring Across Stocks and Markets. Journal of WSEAS Transactions on Business and Economics, Vol. 4, pp. 126-134.

25.Kunovac, D. (2011). Asymmetric correlation on the Croatian equity market. Financial Theory and Practice, Vol. 35, No. 1, pp. 1-24.

26.Ledoit, O., Wolf, M. (2004). Honey, I shrunk the sample covariance matrix. The Journal of Portfolio Management, Vol. 30, No. 4, pp. 110-119.

27.Maillard, S., Roncalli, T., Teiletche, J. (2010). On the Properties of Equally-Weighted Risk Contributions Portfolios. Journal of Portfolio Management, Vol. 36, No. 4, pp. 60-70.

28. Malkiel, B. G., Xu, Y. (1997). Risk and Return Revisited. The Journal of Portfolio Management, Vol. 23, No. 3, pp. 9-14.

29. Martellini, L. (2008). Towards the Design of Better Equity Benchmarks: Rehabilitating the Tangency Portfolio from Modern Portfolio Theory. The Journal of Portfolio Management, Vol. 34, No. 4, pp. 34-41. 
30.Minović, J., Živković, B. (2014). CAPM augmented with liquidity and size premium in the Croatian stock market. Ekonomska istraživanja, Vol. 27, No. 1, pp. 191-206.

31.Odobašić, S., Tolušić, M., Tolušić, Z. (2014). The application of CAPM model on selected shares on the Croatian capital market. Ekonomski vjesnik: Review of Contemporary Entrepreneurship, Business, and Economic Issues, Vol. 27, No. 2, pp. 297-311.

32.Perković, A. (2011). Research of beta as adequate risk measure - is beta still alive? Croatian Operational Research Review, Vol. 2, No. 1, pp. 102-111.

33.Škrinjarić, T., Kojić, V. (2014). Modeliranje prinosa dionica na ZSE pomoću Markovljevih lanaca. Ekonomski pregled: Mjesečnik Hrvatskog društva ekonomista Zagreb, Vol. 65, No. 3, pp. 207-221.

34.Škrinjarić, T., Šego, B. (2016). Dynamic portfolio selection on Croatian financial markets: MGARCH approach. Business Systems Research, Vol. 7, No. 2, pp. 78-90.

35.Škrinjarić, T., Šostarić, N. (2014). Komplementarnost metodologije Markovljevih lanaca i Markowitzevog modela optimizacije portfelja. Ekonomska misao i praksa: časopis Sveučilišta u Dubrovniku, Vol. 23, No. 1, pp. 353-370.

36.Verousis, T., Voukelatos, N. (2018). Cross-sectional dispersion and expected returns. Quantitative finance, Vol. 18, No. 5, pp. 813-826.

37.Zoričić, D., Dolinar, D., Lovretin Golubić, Z. (2018a). A test of global minimum variance portfolio in the Croatian capital market. In: Book of proceedings of 7th International Scientific Symposium Economy of Eastern Croatia - Vision and Growth. Osijek: Sveučilište Josipa Jurja Strossmayera u Osijeku, Ekonomski fakultet u Osijeku, pp. 1165-1173.

38.Zoričić, D., Dolinar, D., Lovretin Golubić, Z. (2018b). Performance Analysis of FundamentallyWeighted Indices in the Croatian Capital Market. Zagreb International Review of Economics \& Business, Vol. 21, Special Conference Issue, pp. 43-53.

\section{About the authors}

Denis Dolinar, PhD, graduated in 2006 from the Faculty of Economics and Business of the University of Zagreb. From December 2006 until August 2008 he worked as an equity analyst at the Raiffeisen Consulting in Zagreb where he conducted stock valuations of several listed Croatian companies. Currently, Denis Dolinar is an assistant professor at the Department of Managerial Economics, Faculty of Economics and Business, University of Zagreb. In 2015, he obtained a PhD degree from the University of Zagreb. The title of his PhD thesis is "Identification of Systematic Risk Factors and Possibility of Applying Factor Models to the Croatian Stock Market". He has coauthored more than 10 peer-reviewed scientific papers and attained many scientific conferences, seminars and workshops. He regularly serves as a paper-reviewer and as a member of the organisation/editorial board for scientific journals and conferences. His research interest is focused on corporate finance, investment analysis, equity valuation, capital budgeting and portfolio management. In his professional work, he deals with the security valuation and portfolio management issues specific to lessdeveloped and emerging capital markets. He is a member of the Croatian Association of Financial Analysts (HUFA). The author can be contacted at ddolinar@efzg.hr.

Davor Zoričić, PhD, is an assistant professor at the Department of Managerial Economics, Faculty of Economics and Business, University of Zagreb. He received his Ph.D. from the University of Zagreb for his research on yield curve modelling possibilities in the Croatian financial market. His research interests cover primarily topics in the field of financial economics, particularly investments and corporate finance. Also, he is a team member on the research project "Electric Vehicle Battery Swapping Station" funded by the Croatian Science Foundation. Furthermore, he currently serves as a 
member of the Supervisory Board and the Audit Committee of the Central Depository \& Clearing Company Inc. In 2006 he passed the Investment Advisor Exam organized by the Croatian Financial Services Supervisory Agency. In 2007 he spent 3 months as a visiting scholar at the University of California, Berkeley. He is a member of the Croatian Association of Financial Analysts and of the Croatian Statistical Association. The author can be contacted at dzoricic@efzg.hr.

Zrinka Lovretin Golubić graduated in 2010 from the Faculty of Economics and Business of the University of Zagreb. From 2010 until 2017 she worked in INA-INDUSTRIJA NAFTE Ltd. in the Funding Department of the Treasury Sector on different positions and the last two years as a funding expert. Her work included preparing financial plans and managing the financial covenants. She was included in negotiations and signing of various loan facility agreements as well as the analysis and control of subsidiaries from the treasury's point of view. Currently, she is working as a teaching and research assistant at the Department of Managerial Economics, Faculty of Economics and Business, University of Zagreb and attending a university postgraduate (doctoral) study programme. Her research interest is focused on investment analysis, portfolio management and corporate finance. She is a member of the Croatian Statistical Association. The author can be contacted at zlovretin@efzg.hr. 